DOI: 10.32844/2222-5374-2020-104-2.32

УДК: 342.9

Панов В. В.,

здобувач наукової лабораторії з проблем

превентивної діяльності та запобігання корупції

Національної академії внутрішніх справ

\title{
ПОРЯДОК ЗАСТОСУВАННЯ ДИСЦИПЛІНАРНИХ СТЯГНЕНЬ ДО ДЕТЕКТИВІВ НАЦІОНАЛЬНОГО АНТИКОРУПЦІЙНОГО БЮРО УКРАЇНИ
}

Актуальність статті полягає в тому, що обрання Україною курсу євроінтеграції зумовлює ініціювання зі сторони останньої перегляду законодавчої регламентації роботи правоохоронних органів, вдосконаленню їх діяльності та підвищення рівня довіри. Становлення ефективної, незаангажованої та прозорої силової структури, покликаної боротися з корупційною складовою, є однією із важливих державних цілей ребормування, оскільки ефективне функціонування державних органів, зокрема, та держави, у цілому, можливе лише при наявності високоефективних некорумпованих державних органів та відсутності неправової особистої матеріальної зацікавленості посадових осіб. Метою статті є проведення аналізу порядку застосування дисциплінарного стягнення відносно детективів Національного бюро та визначення сутності цього виду стягнення. Стаття присвячена визначенню порядку застосування дисциплінарних стягнень до детективів НАБУ. Визначено, що дисциплінарним стягненням, яке застосовується до детектива Національного бюро можна визначити захід правового впливу, як міра покарання за скоєння проступку детективами бюро, з метою виховання свідомо-якісного ставлення до службових обов'язків та результату своєї діяльності, неухильного дотримання службової дисципліни. Зроблено висновок, що метою застосування дисциплінарних стягнень до детективів НАБУ є цілеспрямований виховний вплив на детективів Національного бюро, які скоїли дисциплінарний проступок, з метою зміцнення відповідальності та дотримання службової дисципліни, попередження вчинення проступків у майбутньому. Зроблено висновок, що дисциплінарне стягнення, яке застосовується до детектива Національного бюро - це захід правового впливу, як міра покарання за скоєння проступку детективами бюро, з метою виховання свідомо-якісного ставлення до службових обов'язків та результату своєї діяльності, неухильного дотримання службової дисципліни. Відповідно його метою є цілеспрямований виховний вплив на детективів Національного бюро, які скоїли дисциплінарний проступок, з метою зміцнення відповідальності та дотримання службової дисципліни, попередження вчинення проступків у майбутньому.

Ключові слова: дисциплінарне стягнення, детектив НАБУ, порядок застосування дисциплінарних стягнень, Дисциплінарна комісія, дисциплінарна відповідальність. 
Актуальність теми. Обрання Україною курсу євроінтеграції зумовлює ініціювання зі сторони останньої перегляду законодавчої регламентації роботи правоохоронних органів, вдосконаленню їх діяльності та підвищення рівня довіри. Становлення ефективної, незаангажованої та прозорої силової структури, покликаної боротися з корупційною складовою, є однією із важливих державних цілей реформування, оскільки ефективне функціонування державних органів, зокрема, та держави, у цілому, можливе лише при наявності високоефективних некорумпованих державних органів та відсутності неправової особистої матеріальної зацікавленості посадових осіб.

Стан дослідження. Останнім часом дослідженням особливостям притягнення до відповідальності за проступки займалися різні вчені-адміністративісти, як: О.А. Абрамова, Г.В. Атаманчук, О.М. Бандурка, Д.М. Бахрах, Ю.П. Битяк, В.С. Венедиктов, І.П. Голосніченко, М.І. Данченко, В.К. Колпаков, О.В. Кузьменко, О.Д. Новак, О.Ю. Оболенський, В.В. Середа, О.Ю. Синявська, М.М. Сперанський, М.М. Тищенко, В.В. Форманюк та інші. Однак грунтовне дослідження застосування дисциплінарного стягнення відносно детективів Національного бюро на сьогодні не здійснювалося, тому потребує подальшого вивчення та аналізу.

Метою статті $\epsilon$ проведення аналізу порядку застосування дисциплінарного стягнення відносно детективів Національного бюро та визначення сутності цього виду стягнення.

Виклад основного матеріалу. Особливий порядок із визначенням процедури розгляду матеріали службового розслідування, яке проводилося працівником внутрішнього контролю, передбачено Положенням про Дисциплінарну комісію Національного антикорупційного бюро України, затверджене Наказом НАБУ від 14.07.2020 № 87.

Дисциплінарна комісія, основне завдання, якої ми вже зазначали вище, - розгляд питання про застосування дисциплінарного стягнення до детектива та працівників Національного бюро. Рішення комісія приймає більшістю голосів присутніх.

Під час розгляду матеріалів службового розслідування на засідання можуть запрошуватися: працівник Національного бюро, стосовно якого розглядається питання притягнення до дисциплінарної відповідальності; працівник (працівники) підрозділу внутрішнього контролю; інші працівники Національного бюро [1].

Більш того, члени Дисциплінарної комісії під час розгляду питання про застосування дисциплінарного стягнення до детектива та працівників Національного бюро наділені значним колом прав.

Так, відповідно до п. 19 Положення про Дисциплінарну комісію Національного антикорупційного бюро України член Комісії має право: вносити пропозиції про розгляд на засіданнях Комісії питань, що належать до їі компетенції; брати участь в обговоренні питань порядку денного засідання Комісії, а якщо вони стосуються інформації з обмеженим доступом - за наявності дозволу чи доступу до такої інформації; вивчати чи отримувати матеріали, подані на розгляд Комісії; отримувати від працівників Національного бюро усні чи письмові пояснення, інші матеріали та проводити консультації з фахівцями з питань, пов'язаних із проведенням службового 
розслідування; висловлювати власну думку з питань, що розглядаються; брати участь у прийнятті рішення шляхом відкритого голосування; брати участь у режимі відеоконференції; викладати в межах строку для складання висновку Комісії письмово окрему думку як додаток до висновку Комісії, що $є$ його невід'ємною частиною [1].

Слід звернути увагу, що під час розгляду дисциплінарної справи у разі неналежного виконання членом Дисциплінарної комісії своїх обов'язків, останнього можуть виключити наказом Директора Національного бюро зі складу комісії, або здійснити заміну цього члена. Також Положення про Дисциплінарну комісію Національного антикорупційного бюро України передбачена можливість взяття відводу або самовідводу члена комісії. Але, вказаним Положенням залишилося поза увагою подальше проходження процедури розгляду дисциплінарної справи. Цілком логічно, що розгляд справи має продовжуватися далі, крім випадків, коли при заміні складу, відводу (самовідводу) члена комісії склалася ситуація щодо неможливості роботи комісії.

Для уникнення неточностей у регламентації процедури розгляду дисциплінарної справи та складання проєкту висновку з визначенням рекомендованого виду дисциплінарного стягнення, пропонуємо доповнити п. 21 Положення про Дисциплінарну комісію Національного антикорупційного бюро, виклавши у такій редакції:

У разі заміни, задоволення відводу (самовідводу), виключення члена Комісії зі її складу, який бере участь у розгляді дисциплінарної справи, справа продовжується розглядатися Комісією у тому ж складі з введеним (заміненим) членом.

У разі заміни, задоволення відводу (самовідводу), виключення членів всієї Комісії зі її складу, що беруть участь у розгляді дисциплінарної справи, утворюється новий склад Комісії без участі замінених, відведених (самовідведених), виключених осіб з попереднього складу. У такому випадку розгляд справи починається з початку.

Тепер докладніше зупинімося на підставах відводу (самовідводу) членів Дисциплінарної комісії. Так, відповідно до п. 21 Положення про Дисциплінарну комісію Національного антикорупційного бюро України член Комісії не має права брати участь у прийнятті рішення та зобов'язаний не вчиняти будь-яких дій, і підлягає відводу (самовідводу) під час вирішення питання, якщо: він є членом сім'ї працівника Національного бюро, стосовно якого вирішується питання про притягнення до дисциплінарної відповідальності, а також чоловік, дружина, батько, мати, вітчим, мачуха, син, дочка, пасинок, падчерка, рідний та двоюрідний брати, рідна та двоюрідна сестри, рідний брат та сестра дружини (чоловіка), племінник, племінниця, рідний дядько, рідна тітка, дід, баба, прадід, прабаба, внук, внучка, правнук, правнучка, зять, невістка, тесть, теща, свекор, свекруха, батько та мати дружини (чоловіка) сина (дочки), усиновлювач чи усиновлений, опікун чи піклувальник, особа, яка перебуває під опікою або піклування; стало відомо про інші обставини, які можуть вплинути на об’єктивність та неупередженість члена Комісії [1].

На нашу думку, підстави відводу (самовідводу) члена Дисциплінарної комісії $\epsilon$ невичерпними не передбачають усіх обставин, які можуть впли- 
нути на об’єктивність та неупередженість його рішень під час розгляду справи. Так, поза увагою залишилось можливість перебування у службових відносинах з особою, що вчинила дисциплінарний проступок, оскільки до п’яти осіб, що входять до складу комісії, три з них є працівниками Національного бюро, а два - члени Ради громадського контролю Національного бюро. Також, до цих вказаних обставин, які можуть вплинути на об'єктивність та неупередженість рішень члена комісії, можна віднести його участь з'ясуванні обставин, які мають значення для справи, консультування у цій справі; проводив перевірку, експертизу матеріалів, що використовуються під час розгляду дисциплінарної справи тощо.

Для здійснення незацікавленого, неупередженого розгляду дисциплінарної справи та складання об’єктивного висновку з визначенням рекомендованого виду стягнення, пропонуємо доповнити перелік підстав для здійснення відводу (самовідводу) члена Дисциплінарної комісії, доповнивши п. 21 Положення абзацом четвертим у наступній редакції:

Член Комісії не має права брати участь у прийнятті рішення та зобов'язаний не вчиняти будь-яких дій, і підлягає відводу (самовідводу) під час вирішення питання, якщо: ...

3) він перебував або перебуває в службових відносинах або в іншій залежності від працівника, стосовно якого вирішується питання про притягнення до дисциплінарної відповідальності;

4) він проводив перевірку, експертизу матеріалів, що використовуються під час розгляду дисциплінарної справи;

5) брав участь у з'ясуванні обставин, які мають значення для справи, здійснював консультування у цій справі.

Відвод може заявити голова, тимчасово обраний головуючий чи інший член Комісії, а також працівник, якого притягають до дисциплінарної відповідальності, чи інша заінтересована особа. Відвод з обгрунтуванням його підстав надсилається Комісії у формі письмової заяви. Голова Комісії зобов'язаний ознайомити члена Комісії із заявою про його відвід та підставами для відводу на засіданні Комісії або шляхом надсилання відповідної копії заяви на надану членом Комісії з числа Ради електронну пошту, а працівників Національного бюро - службову електронну пошту [1].

Дана норма не позбавляє можливості члену Дисциплінарної комісії пояснити обставини, які стали причиною оголошення останньому відвод.

Рішення про відвід (самовідвід) члена Комісії приймається простою більшістю присутніх на засіданні її членів, крім члена Комісії, стосовно якого вирішується питання щодо відводу (самовідводу). У разі рівного розподілу голосів, вирішальним $є$ голос голови Комісії, а у разі його відсутності - тимчасово обраного головуючого [1].

Варто звернути увагу, що аналізоване Положення враховує вимоги Закону України «Про запобігання корупції», шляхом не допущення випадків спроби врегулювати конфлікту інтересів у роботі членів комісії, голови.

Також, члени Дисциплінарної комісії мають право на основі підстав, що дають можливість оголосити відвод (самовідвод) цим членам, звенутися до Директора Національного бюро з питанням ініціювання перед Радою можливості позбавлення повноважень та виключення його зі складу Комісії та/або заміни цього члена Комісії [1]. 
Як ми вже зазначали вище, Положенням про Дисциплінарну комісію Національного антикорупційного бюро України передбачена процедура розгляду дисциплінарної справи та обрання рекомендованого виду дисциплінарного стягнення, яке відображається у проекті висновку.

Так, розгляд матеріалів службового розслідування на засіданні Комісії починається із заслуховування доповіді члена Комісії, який за дорученням голови Комісії вивчав такі матеріали, після чого заслуховуються присутні на засіданні Комісії інші її члени, працівник, за наявності, або інші особи, запрошені Комісією, а також вивчається та аналізується інша інформація [1].

Під час розгляду та вивчення матеріалів службового розслідування на засіданні Комісії, останніми при обранні рекомендованого виду дисциплінарного стягнення для детективів Національного бюро, враховується тяжкість проступку, обставини, за яких він був вчинений.

Пункт 24 вказаного вище Положення надає вичерпний перелік обставин, які беруться до уваги, а саме: враховуватися тяжкість проступку, обставини, за яких його скоєно, заподіяна шкода, попередня поведінка особи та визнання нею своєї вини, її ставлення до виконання службових обов'язків, рівень кваліфікації тощо [1].

За результатами розгляду дисциплінарної справи Дисциплінарна комісія приймає рішення про наявність чи відсутність у діях детектива Національного бюро складу дисциплінарного проступку, підстави для його притягнення до дисциплінарної відповідальності з визначенням рекомендованого виду дисциплінарного стягнення.

У разі спливу терміну (строку) застосування дисциплінарного стягнення до детектива Національного бюро, який вчинив дисциплінарний проступок, відповідна Комісія зазначає причини його пропуску та рекомендує не застосовувати жоден із видів стягнення.

Строки накладання дисциплінарних стягнень передбачені Дисциплінарним статутом органів внутрішніх справ України ст. 16, яка встановлює строк до одного місяця з дня, коли про проступок стало відомо начальнику [2]. Також, частина 3 вказаної статті визначає терміни, коли не може бути накладено дисциплінарне стягнення: дисциплінарне стягнення не може бути накладено, якщо з дня вчинення проступку минуло більше півроку. У цей період не включається строк проведення службового розслідування або кримінального провадження або провадження у справі про адміністративне правопорушення [2].

Повертаючись до аналізу висновку з визначенням рекомендованого виду дисциплінарного стягнення, який складається членом-доповідачем Дисциплінарної комісії, не пізніше п’яти робочих днів після закінчення засідання Комісії. Дане рішення підписується членами Дисциплінарної Комісії, які були присутніми на засіданні у тому числі й тих, які брали участь у режимі відеоконференції.

Проект висновку рекомендованого виду дисциплінарного стягнення має бути виваженим та обгрунтованим з урахуванням всіх обставин. Саме тому у тому зазначаються результати розглянутих матеріалів службового розслідування, включаючи й пояснення осіб, які мають відношення до справи, самого працівника Національного бюро, відносно якого прово- 
диться розслідування, факти, які стали підставою проведення розслідування тощо.

Відповідно до Інструкції про порядок проведення службового розслідування стосовно працівників Національного антикорупційного бюро України, затвердженої наказом Директора Національного антикорупційного бюро України від 23.10.2015 № 4, а також Положення про Дисциплінарну комісію Національного антикорупційного бюро України, у висновку зазначається: склад членів Комісії, присутніх на засіданні; посада, прізвище, ім'я та по батькові, рік народження, освіта, стаж державної служби - щодо державних службовців та вислуга років - щодо осіб начальницького складу, ранг державного службовця або спеціальне звання особи начальницького складу; факти і суть подій, які стали підставою для проведення службового розслідування, оцінка результатів службової діяльності такої особи, види заохочення та дисциплінарного стягнення, які раніше застосовувались до працівника; заяви, клопотання, пояснення, а також зауваження працівника, щодо якого вирішується питання про притягнення до дисциплінарної відповідальності, обгрунтування про їх відхилення чи взяття за переконання; причини та умови, що призвели до вчинення дисциплінарного проступку; підстави притягнення працівника до дисциплінарної відповідальності; обставини, що можуть свідчити про відсутність у діях дисциплінарного проступку; обставини, що пом'якшують або обтяжують відповідальність особи, щодо якої проводиться службове розслідування; висновок про наявність або відсутність у діях такої особи дисциплінарного проступку та підстав для її притягнення до дисциплінарної відповідальності з визначенням рекомендованого виду дисциплінарного стягнення, якщо такий може бути застосовано; інші відомості, необхідні для прийняття рішення щодо працівника, стосовно якого вирішується питання дисциплінарної відповідальності [3; 2].

Як ми вже зазначали вище, у висновку вказується рекомендований вид дисциплінарного стягнення до детектива Національного бюро, який вчинив дисциплінарний проступок.

Законом України «Про запобігання корупції» ч. 1 ст. 65-1 зазначено, що за вчинення корупційних або пов'язаних з корупцією правопорушень особи начальницького складу Національного антикорупційного бюро України притягаються до кримінальної, адміністративної, цивільно-правової та дисциплінарної відповідальності у встановленому законом порядку [4]. У свою чергу, ч. 2 вказаної статті встановлює, що особа, яка вчинила корупційне правопорушення або правопорушення, пов'язане з корупцією, однак судом не застосовано до неї покарання або не накладено на неї стягнення у виді позбавлення права обіймати певні посади або займатися певною діяльністю, пов'язаними з виконанням функцій держави або місцевого самоврядування, або такою, що прирівнюється до цієї діяльності, підлягає притягненню до дисциплінарної відповідальності у встановленому законом порядку [4].

Зовсім інша ситуація застосовується щодо особи, відносно якої набрало законної сили рішення суду.

Так, особа, уповноважена на виконання функцій держави або місцевого самоврядування, стосовно якої набрало законної сили рішення суду 
про визнання необгрунтованими активів та їх стягнення в дохід держави, підлягає звільненню з посади в установленому законом порядку [5].

Із зазначеного вище випливає, що детектив Національного бюро, який вчинив корупційне правопорушення або правопорушення, пов'язане з корупцією, однак судом відносно нього не було застосовано покарання або позбавлено права обіймати керівні посади, підлягає притягненню до дисциплінарної відповідальності у встановленому законом порядку. У свою чергу, єдиною підставою звільнення детектива Національного бюро, передбаченою ст. 65-1 Закону України «Про запобігання корупції» $є$ факт набрання законної сили рішенням суду про визнання необгрунтованими активів та їх стягнення в дохід держави.

Відповідно, за результатами розгляду дисциплінарного розслідування відносно детектива Національного бюро Дисциплінарна комісія буде у висновку рекомендувати вид дисциплінарного стягнення, передбаченого ст. 12 Дисциплінарного статуту органів внутрішніх справ України з перспективою можливості у подальшому обіймати керівні посади, оскільки останній не передбачає позбавлення такої можливості особи, яка була замішана у корупційному правопорушенні або правопорушенні, пов'язаним з корупцією.

Тому, з метою запобігання та попередження корупційних проявів серед осіб начальницького складу Національного бюро України пропонуємо доповнити ст. 12 Дисциплінарного статуту органів внутрішніх справ України наступним видом дисциплінарного стягнення:

до особи начальницького складу, яка вчинила корупційне правопорушення або правопорушення, пов'язане з корупцією, однак судом не застосовано до неї покарання або не накладено на неї стягнення у виді позбавлення права обіймати певні посади або займатися певною діяльністю, пов'язаними з виконанням функцій держави або місцевого самоврядування, або такою, що прирівнюється до цієї діяльності, застосовується дисциплінарне стягнення у вигляді позбавлення можливості у подальшому обіймати керівні посади в органах внутрішніх справ.

Як ми вже зазначали вище, висновок з рекомендованим видом дисциплінарного стягнення складається членом-доповідачем Дисциплінарної комісії, не пізніше п’яти днів після засідання цієї комісії.

Відповідно до п.27 Положення про Дисциплінарну комісію Національного антикорупційного бюро України складений проєкт висновку члени Комісії погоджують протягом трьох робочих днів, у тому числі через надану ними електронну пошту, а також можуть його підписати з використанням електронного цифрового підпису у разі неможливості підписання власноручно [1].

Позитивною стороною даного Положення $є$ врахування сьогоднішніх реалій - введення карантинних обмежень, запроваджених у зв'язку з недопущенням розповсюдженням та недопущення поширення коронавірусної хвороби (COVID-19). Мова йде про впровадження та врахування можливості взяття участі в засіданні Дисциплінарної комісії в режимі відеозв'язку та використання цифрового підпису членами комісії у разі неможливості підписання власноруч. Вказана норма дає можливість своєчасно в становленні законодавством строки здійснити розгляд матеріалі дисциплінарного 
розслідування по суті та визначення рекомендованого виду дисциплінарного стягнення.

У разі використання одним із членів Комісії цифрового підпису інші члени Комісії підписують власноручно виведений на папір, підписаний цифровим підписом, проєкт висновку Комісії. Висновок засідання Комісії не пізніше ніж протягом трьох робочих днів з дня його підписання секретарем Комісії направляється (надається) Директору Національного бюро для прийняття відповідного управлінського рішення [1]. Слід звернути увагу, що Пропозиції, викладені у висновку Комісії для Директора Національного бюро, мають рекомендаційний характер [1].

Прийняття остаточного рішення з притягненням детектива Національного бюро, який скоїв дисциплінарне порушення, відповідно до Закону України «Про Національне антикорупційне бюро України» покладається виключно на Директора бюро (ст. 28), який має прийняти відповідне рішення протягом 10 календарних днів з дня отримання висновку Дисциплінарної комісії. Також законодавець дає можливість оскаржити у судовому порядку вказане рішення.

На нашу думку, вказана норма не враховує випадки перебування Директора бюро у відрядженні, відсутність його у період непрацездатності чи з інших поважних причин, що може викликати прострочення прийняття рішення відносно накладання стягнення на порушника дисципліни. Як ми вже зазначали вище, ст. 16 Дисциплінарного статуту органів внутрішніх справ України обмежує термін накладання дисциплінарного стягнення.

3 урахуванням викладеного вище, для уникнення прострочення терміну накладання Директором Національного бюро дисциплінарного стягнення на детектива Бюро, ми вважаємо за доцільне, доповнити п. 27 Положення про Дисциплінарну комісію Національного антикорупційного бюро України, передбачивши поважні підстави, виклавши у наступній редакції:

Директор Національного бюро протягом 10 календарних днів 3 дня отримання висновку Комісії приймає відповідне рішення, не враховуючи періоду тимчасової непрацездатності, перебування у відпустці або з інших поважних причин.

Висновки. Отже, дисциплінарне стягнення, яке застосовується до детектива Національного бюро - це захід правового впливу, як міра покарання за скоєння проступку детективами бюро, з метою виховання свідомо-якісного ставлення до службових обов'язків та результату своєї діяльності, неухильного дотримання службової дисципліни. Відповідно його метою $\epsilon$ цілеспрямований виховний вплив на детективів Національного бюро, які скоїли дисциплінарний проступок, з метою зміцнення відповідальності та дотримання службової дисципліни, попередження вчинення проступків у майбутньому.

На підставі проведеного аналізу спеціального законодавства, яке регулює порядок застосування дисциплінарного стягнення на детективів Національного бюро, є доцільним внести низку доповнень та уточнень з метою їх врегулювання з нормами антикорупційного законодавства, а також передбаченням додаткових видів дисциплінарних стягнень. Це дасть можливість керівникові Національного бюро здійснювати диферен- 
ційований та індивідуальний підхід під час врахування рішення та рекомендацій Дисциплінарної комісії до накладання відповідного стягнення відносно детективів та інших працівників Бюро з урахуванням тяжкості проступку, настання шкідливих наслідків у разі його вчення, а також обтяжуючих чи пом'якшуючих обставин відповідальності порушника.

\section{СПИСОК ВИКОРИСТАНИХ ДЖЕРЕЛ}

1. Про затвердження Положення про Дисциплінарну комісію Національного антикорупційного бюро України: Наказ Національного антикорупційного бюро України від 14.07.2020 № 87. URL: https://nabu.gov.ua/ sites/default/files/page_uploads/15.07/nakaz_ostatochnyy.pdf.

2. Про затвердження Інструкції про порядок проведення службового розслідування стосовно працівників Національне антикорупційне бюро України : Наказ Національного антикорупційного бюро України від 23 жовтня 2015 року № 4. URL: https://nabu.gov.ua/sites/default/files/page_ uploads/23.10/sluzhbovirozsliduvannya.pdf.

3. Дисциплінарний статут органів внутрішніх справ: Закон України від 22 лютого 2006 року № 3460-IV. URL: https://zakon.rada.gov.ua/laws/ show/3460-15\#n47.

4. Про запобігання корупції : Закон України від 14.10.2014 № 1700-VII. URL: https://zakon.rada.gov.ua/laws/show/3460-15\#n47.

\section{Panov}

\section{PROCEDURE FOR APPLYING DISCIPLINARY PENALTIES TO DETECTIVES OF THE NATIONAL ANTI-CORRUPTION BUREAU OF UKRAINE}

The relevance of the article is that the choice of Ukraine's European integration course presupposes the initiation by the latter of a revision of the legislative regulation of the work of law enforcement agencies, improvement of their activities and increase of the level of trust. The establishment of an effective, impartial and transparent force structure designed to combat corruption is one of the important state goals of the reform, as the effective functioning of state bodies, in particular, and the state in general, is possible only in the presence of highly effective non-corrupt state bodies. interest of officials. The purpose of the article is to analyze the procedure for applying disciplinary sanctions against detectives of the National Bureau and to determine the essence of this type of punishment. The article is devoted to determining the procedure for applying disciplinary sanctions to NABU detectives. It is determined that a disciplinary sanction applied to a detective of the National Bureau can be defined as a measure of punishment as a measure of punishment for misconduct by detectives of the bureau, in order to cultivate a conscious attitude to duties and performance, strict discipline. It is concluded that the purpose of applying disciplinary sanctions to $N A B U$ detectives is to purposefully educate detectives of the National Bureau who have committed disciplinary misconduct, in order to strengthen accountability and discipline, prevent future misdemeanors. It is concluded that the disciplinary sanction applied to the detective of the National Bureau is a measure of legal influence, as a measure of punishment for misconduct by detectives of the 
bureau, in order to cultivate a conscious attitude to duty and performance, strict discipline. Accordingly, its purpose is a purposeful educational influence on the detectives of the National Bureau, who committed a disciplinary offense, in order to strengthen the responsibility and observance of official discipline, to prevent misconduct in the future.

Keywords: disciplinary sanction, NABU detective, procedure for application of disciplinary sanctions, Disciplinary Commission, disciplinary responsibility. 